\title{
Dados de uma atividade pedagógica para a leitura de imagens de violência, no Ensino de História
}

\author{
Paulo Augusto Tamanini ${ }^{1}$ \\ Ana Meyre de Morais ${ }^{2}$
}

\begin{abstract}
RESUMO
$\mathrm{O}$ artigo apresenta uma atividade pedagógica para a leitura de imagens de cunho violento presentes em livros de História. Para tanto, se serve de uma imagem colhida no livro História Sociedade \& Cidadania, La Paraguaya, do artista uruguaio Juan Manuel Blanes, datada do ano de 1880. O aporte teórico acerca da leitura de imagens serve-se de Burke (2004), Santaella (2012) e Bittencourt (2009); sobre o uso da imagem como ferramenta pedagógica em sala de aula, referencia-se em Fonseca (2003), Monteiro e Penna (2011), Alvarenga e Araújo (2006). A atividade didática mostrou que as imagens prendem a atenção do alunado para o fato de a violência existir e estar presente, por vezes, de modo, subliminar, inclusive nos livros didáticos.
\end{abstract}

PALAVRAS-CHAVE: Atividade pedagógica. Leitura de imagens. Ensino de História. Violência.

Notes of a pedagogical activity for reading images of violence, in History Teaching

\begin{abstract}
The article presents a pedagogical activity for reading of images of a violent nature present in history books. To this end, it uses an image from the book History Society \& Citizenship: La Paraguaya, by the
\end{abstract}

${ }^{1}$ Doutor em História. Docente da Faculdade de Letras e Artes e do Programa de Pós-Graduação em Ensino da Universidade do Estado do Rio Grande do Norte (UERN), Mossoró, RN, Brasil. Orcid: https://orcid.org/0000-00016963-2952.E-mail: paulotamanini@uern.br.

${ }^{2}$ Mestra em Ensino. Universidade Federal Rural do Semiárido (UFERSA), Mossoró, RN, Brasil. Orcid: http://orcid.org/0000-0001-7394-0579. E-mail: $\underline{\text { ameyremorais@ gmail.com. }}$ 
Uruguayan artist Juan Manuel Blanes, dated to the year 1880. The theoretical contribution about image reading uses Burke (2004), Santaella (2012) and Bittencourt (2009); on the use of image as a pedagogical tool in the classroom, refer to Fonseca (2003), Monteiro, Penna (2011), Alvarenga and Araújo (2006). The didactic activity showed that the images hold the students' attention to the fact that violence exists and is present in a subliminal way, sometimes in textbooks.

KEYWORDS: Pedagogical activity. Reading images. History teaching. Violence.

Datos de una actividad pedagógica para la lectura de imágenes de violencia, en Didáctica de la Historia

\section{RESUMEN}

El artículo presenta una actividad pedagógica para la lectura de imágenes de carácter violento presentes en los libros de historia. Para eso, utiliza una imagen del libro History Society \& Citizenship: La Paraguaya, del artista uruguayo Juan Manuel Blanes, fechada en 1880. La contribución teórica sobre la lectura de imágenes utiliza Burke (2004), Santaella (2012) y Bittencourt (2009); sobre el uso de la imagen como herramienta pedagógica en el aula, consulte Fonseca (2003), Monteiro, Penna (2011), Alvarenga y Araújo (2006). La actividad didáctica mostró que las imágenes atraen la atención de los estudiantes sobre el hecho de que la violencia existe y está presente de manera subliminal, a veces en los libros de texto.

PALABRAS CLAVE: Actividad pedagógica. Lectura de imágenes. Enseñanza de historia. Violencia.

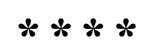




\section{Introdução}

Ocupando lugar exponencial nas comunicações, interações e troca de saberes, as imagens adentram também nas salas de aulas como um dos elementos facilitadores da didática. Em um momento tão singular em que se pontificam as mensagens instantâneas, em que a visualidade parece substituir a escrita, ensinar História sem acompanhar a carga informacional das imagens, parece dar razão à fantasia de que a História, ao tratar do passado, deixou de se interessar pelas coisas do presente. Quebrando o paradigma, o Ensino de História tenta cada vez mais utilizar-se das ferramentas de informação mais atuais para do passado falar, discorrer, analisar, investigar e construir as narrativas.

A leitura é por certo um modo de decodificar, de decifrar, de interpretar signos. Se a grande maioria se diz letrada nos textos escritos, outra tanta deixa lacunas quando se depara com figuras, imagens, desenhos, ícones etc. porque apenas enxerga as imagens, mas não as lê. Analisadas de modo minucioso, as imagens são percebidas mais que um adendo ao texto escrito; são modos de representação e compreensão de mundo e que chegam aos livros didáticos com intuito de também ensinar. Contudo, a capacitação dos profissionais do Ensino para uma leitura acerca dos conteúdos visuais torna-se urgente para que eles possam desempenhar com sucesso uma de suas finalidades mais prementes: informar, instruir, dizer, educar.

Este artigo vai ao encontro dessa falta e tenta refletir sobre como imagens podem ser interpretadas, lidas, assimiladas, hermeneutizadas, decifradas em seus signos e conteúdos visuais. No ambiente escolar, o uso das imagens tem demandado tratamento específico por serem potenciais mediadoras de saberes. Isso porque, educar o olhar para facilitar a leitura e interpretação do passado passa pela reflexão sobre o modo como os conteúdos visuais, que representam um passado, são abordados. 
Com o objetivo de transformar a sala de aula em um espaço favorável à aplicabilidade das imagens como forma de conhecimento dinâmico, significativo e envolvente, pensamos em uma atividade pedagógica para tratar da leitura das imagens de cunho violento, no Ensino de História. Para tanto, nos servimos de La Paraguaya, obra do artista uruguaio Juan Manuel Blanes, datada do ano de 1880, disponibilizada em manuais didáticos de História do Ensino Médio.

Junto à imagem, pensamos em um questionário, com perguntas estruturadas, para dar acompanhamento ao processo de leitura de imagens sem correr riscos de desvios, achismos e subjetivações ou excessos que fugissem do escopo da proposta. As respostas inventariadas dão uma ideia sobre a relação entre os discentes e as ilustrações presentes nos didáticos.

\section{A sala de aula como espaço de atividade pedagógica para a leitura de imagens no Ensino de História}

A sala de aula também é um lugar destinado às práticas culturais e de cunho formativo onde técnicas e habilidades são desenvolvidas somadas às criatividades de professores e alunos. Pedagogicamente, também pode ser compreendida como espaço de formação em que as atividades didáticas dizem respeito ao fazer dos alunos e dos professores que se associam para um mútuo crescimento. Desvelar o que está por dentro desse lugar de cultivo e construção de conhecimentos é entrar num mundo repleto de possibilidades para criações e experimentações pedagógicas. Decorre disso que, na escola, o professor ao tomar a ideia da sala de aula como um espaço de atividade pedagógica para leitura de imagens poderá ministrar suas aulas servindo-se também do visual para mediar conhecimentos propostos pelos livros didáticos.

Como expressão da cultura humana, a imagem tornou-se uma das primeiras tentativas de comunicação e de registro do cotidiano, um dos modos de significar o mundo, uma das maneiras de se relacionar com os 
espaços e com os marcos temporais. Logo, a imagem desde o início figurava-se um elemento possuidor de informações que precisava ser lida em seus aspectos funcionais e não apenas apreciada em sua estética. Por ser passível de interpretação, necessitava-se capacitar profissionais que olhassem a imagem como um artefato que faz uso do simbólico para expressar dizeres. Posteriormente, os conteúdos imagéticos foram redimensionados à categoria de textos deixando de ter apenas funções periféricas como a de somente reforçar o já dito, o já descrito pelas frases e paragráfos, nos livros didáticos, por exemplo.

Nesta combinação e parceria, os livros didáticos apresentam formas de escrita múltiplas em que o discurssivo e o imagético mutuamente se empenham na responsabilidade de ensinar. Dentre as linguagens novas, a iconografia tem-se posicionado como uma forma promissora e que facilita a aprendizagem. Desenvolver no alunado e nos professores a aptidão de interpelar as imagens de modo crítico tem se demonstrado um desafio a ser enfrentado; capacitá-los teórica e metodologicamente para esse novo formato didático revela-se uma preocupação também pertinente.

Muitas imagens que retratam conflitos violentos, hoje são atenuadas, porque, como pensam alguns, expôr a violência convencionou-se ir de encontro a um esforço de civilidade. Contudo, a violência existiu e existe sob diversas naturezas, graus e intensificações, inclusive nos manuais didáticos. Os livros falam dela, mostram-na pelas figuras, ilustrações e fotografias. A violência está recorrentemente presente e representada nas muitas páginas dos livros didáticos. Portanto, o professor como mediador da aprendizagem, sabendo de sua existência nas páginas dos livros didáticos, poderá utilizar-se das ilustrações trazidas, como ferramentas que incentivam uma leitura crítica, realocando o teor visual para além do componente figurativo.

Para dar concretude e exemplificar o que até agora foi exposto, apresentamos a tela La Paraguaya: 
FIGURA 1: La Paraguaya - Juan Manuel Blanes, 1880.

Fonte: BOULOS, 2013, p. 262

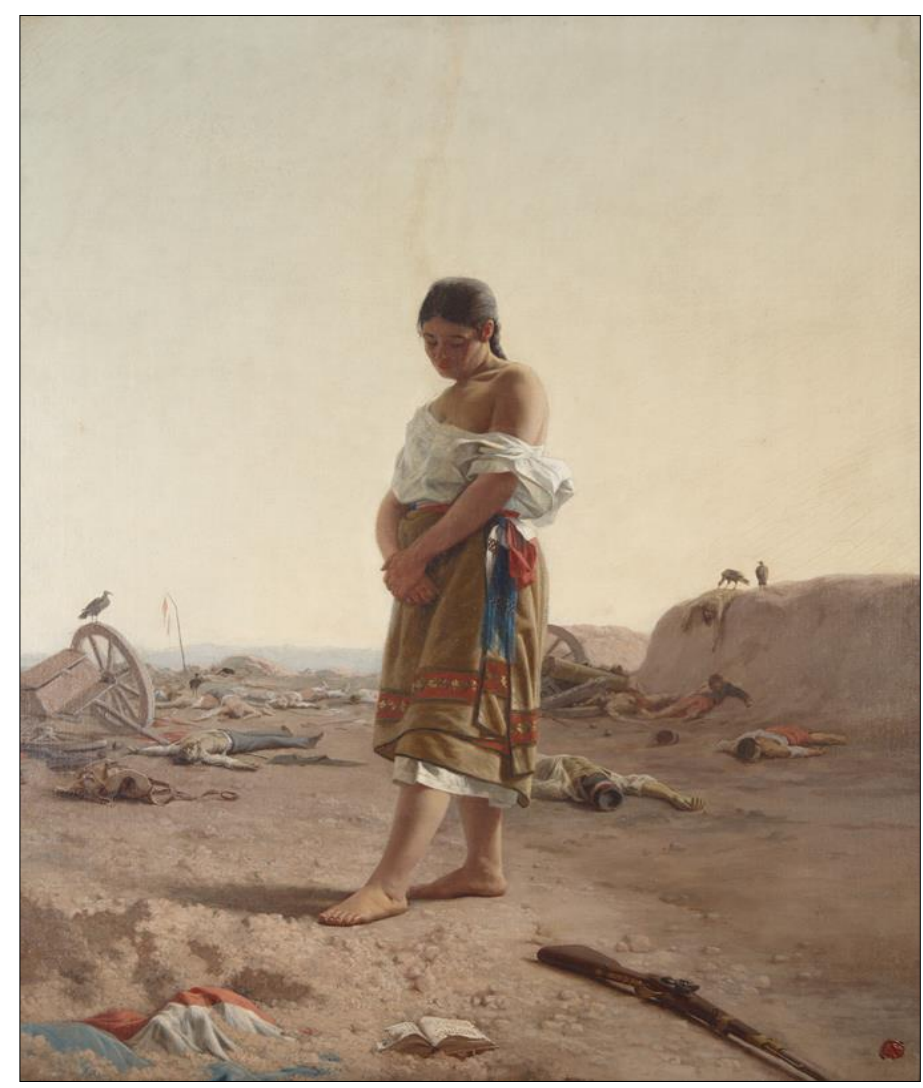

A imagem acima, intitulada La Paraguaya, é uma óleo sobre tela de Juan Manuel Blanes, de 1880, albergada no Museu Nacional de Artes Plásticas, em Montevídeu, no Uruguai, e que, no Brasil, serve de ilustração para um livro didático de História, editado pela editora FTP. A obra de Blanes retrata um campo de batalha em cujo centro pontifica-se uma figura feminina latino-americana com vestes tipicamente indígenas, cabisbaixa, consternada, rodeada por cadáveres, abutres; em outro enquadramento, deixa visível um livro aberto e uma arma. No segundo plano, somada aos corpos inertes, uma espécie de carruagem despedaçada encoberta pela sombra das aves de rapina, torna o cenário ainda mais desolador. Cada parte da cena retratada ali, vista isoladamente, faz parte de um enredo que somado aos outros formam um registro imagético de natureza historiográfica, fruto da percepção de Blanes, acerca "daquilo que o escrito não pode sozinho enunciar" (BURKE, 2004, p. 38). 
Uma vez exposta, a inteireza da imagem, o todo imagético incitou, nos alunos, o surgimento de perguntas de cunho investigativo, tais como: o que teria motivado aquele conflito? Por que a mulher ali retratada se encontra em destaque na pintura? Haveria sofrido algum tipo de violência, qual? Como a historiografia aborda a presença das mulheres nesses conflitos bélicos? Além da mulher, quais outros destaques?

A partir da perspectiva que a imagem foi observada e lida como fonte que incitou perguntas, observa-se que cada enquadramento que se somou e que se juntou aos demais qual um mosaico, narra coletivamente um episódio, uma cena. Assim, cada parte da imagem diz respeito a um episódio e a um instante que enreda uma trama elaborada por meio de formas, cores, traços e sombras, abertas ao escrutíneio dos outros, quais fontes a serem arguidas. Peter Burke assinala que toda fonte deve sofrer a crítica necessária (2004, p. 30) para não se deixar despercebida no conjunto.

Embora La Paraguaya fosse pensada inicialmente como uma tela que representou o conflito armado que ocorreu na América do Sul (1864 - 1870) entre o Paraguai, o Brasil, o Uruguai e a Argentina, hoje, ilustra o capítulo 15 do livro didático de História. Como tantas outras telas acostumadas aos elogios dos críticos da Arte e aos deleites dos refinados espectadores e frequentadores de exposições, servem também, neste agora, aos livros didáticos como peças de amostragem, figuras que ilustram e que ensinam para além do campo da estética; ensinam acerca da vida, do cotidiano dos alunos e professores, das percepções, dos entendimentos; alicerçam diagnósticos críticos da sociedade.

Disposta na parte superior da página do livro didático de História, La Paraguaya apresenta uma singela legenda, contendo somente o nome do artista, título, ano de sua produção e técnica utilizada, além do museu em que se encontra. No lado direito da imagem, um outro pequeno texto, dentro de um balão, chama a atenção na página 262 do livro História Sociedade \& Cidadania 
Repare como o pintor Juan Manuel Blanes recriou o ambiente de desolação e perdas resultantes da guerra em solo paraguaio. Note também a ausência de homens com vida na pintura, o que sugere um fato realmente acontecido: o elevado número de baixas registradas na população masculina paraguaia. (BOULOS JUNIOR, 2013, p. 262).

O autor do livro didático, em uma tentativa de chamar atenção dos alunos para a composição da pintura, certifica que La Paraguaya tem informações, escondidas nos detalhes, e que, por vezes possam ser desapercebidas em uma leitura mais ligeira. Era preciso então estar atento à ilustração e compreendê-la como um artefato de ensino e de aprendizagem.

Santaella (2012, p. 34) ao discorrer sobre o uso das pinturas no ensino, lembra que elas "não mais desfrutam do status de forma quase exclusiva do mundo das artes visuais como foi em séculos anteriores".

Embora não disponha mais dessa exclusividade, ainda hoje, as pinturas continuam a ser importantes para o ensino, sobretudo o de História. Isto porque, as ilustrações, as figuras, os variuados conteúdos imagéticos dos livros didáticos são vistos como fontes privilegiadas de acesso à compreensão de um passado. Ainda assim, são ambíguas nos seus significados porque dependem da interpretação de quem as observa.

Portanto, a composição de Blanes suscita interpretações que independentemente de ser obra artística, proporciona reflexões variadas acerca das experiências humanas, no decurso de um tempo. Mesmo assim, a curiosidade investigativa poderá levantar questões de outras natureza, por exemplo: sobre o artista, os contextos históricos e políticos da produção.

Mas, como se poderia transformar a sala de aula em um espaço dinâmico para fortalecer o ensino de História com uso de imagens? Segundo Fonseca (2003, p. 101), "a escola por ser uma instituição de natureza social, estabelece interação com variados grupos, sujeitos e instituições". Consequentemente, influencia e se deixa influenciar por ela. A autora 
ressalta ainda que, a construção de novas práticas pedagógicas para o ensino também é responsivo dos contextos socioculturais em que a escola está inserida; é resultante do entendimento da escola como instituição, ambiente plural apropriado para a troca e produção de saberes. Logo, a escola é um campo de amostragem para onde converge o que está além das fronteiras de seus muros. O cotidiano das famílias de seus alunos, as preocupações e responsabilidades dos pais, as relações de poder e de interesses nem sempre aceitáveis, as manifestações de amor e ódio que por vezes desembocam em violência extremada.

Fatos violentos, representados por imagens nos livros de História, demandam apropriações e leituras. Nessa linha de pensamento, a mediação do professor é crucial para que haja uma comunhão entre os dizeres da imagem com o mundo externo do aluno e da escola. Se nada significarem para o aluno, as imagens continuarão a ser apenas figurinhas nos livros, sem nada dizer, sem nada ensinar!

Monteiro e Penna (2011), na obra o Ensino de História: saberes em lugar de fronteira, apresenta uma discussão sobre a constituição teóricometodológica de pesquisa voltada para a afinidade entre saberes docentes e escolares nas narrativas da história escolar. Enfatiza os aportes teóricos do campo do Currículo e da Didática, articulando-os aos referenciais de teorias da História e da Retórica, sustentando que a pesquisa sobre Ensino de História é lugar de fronteira, cuja produção de saberes parte dos diálogos, das trocas e dos compartilhamentos de informações.

Portanto, a exequibilidade de uma atividade pedagógica para a leitura de imagens se firma, porque mostra-se oportunidade para o aluno também exercitar a partilha de preocupações que rodeia seu universo. Alunos e professores juntos e empenhados a refletir sobre um cotidiano não muito distante daquele que a maioria dos discentes vive: todos estamos envoltos pelas imagens! Elas nos cercam e dizem algo!

Conforme Fonseca (2003, p. 119), alunos e professores, como sujeitos da ação pedagógica, de forma constante dispõem de ocasiões para investigar 
e produzir conhecimentos. Sendo assim, na busca por uma dinamização nas aulas de História, professores devem considerar o quanto o conhecimento histórico é importante para a formação de cidadãos atuantes na vida em sociedade. Com o desenvolver de posturas participativas, as aulas de História podem interagir e aproximar os conteúdos curriculares com as experiências vividas no cotidiano.

Destarte, a sala de aula é compreendida atualmente, como espaço favorável para o desenvolvimento de práticas pedagógicas inclusivas, críticas, lugar que acomoda professores e alunos para a troca de saberes, e que por isso, institui-se um ambiente de encontro, em cujo recinto se destinam experimentações dinâmicas.

\section{Sala de aula como espaço de partilhas e de percepções acerca de La Paraguaya}

A seleção de uma imagem e o seu respectivo o exercício de leitura baseou-se naquilo que Bittencourt (2009, p. 368) alertou sobre as propostas pedagógicas para o uso de fontes iconográficas em sala de aula. Ela ressalta que para a organização de estudos que tenha como suporte didático a imagem, duas perguntas são imprescindíveis: como selecionar imagens para o trabalho a ser desenvolvido em sala? E, como se dá a leitura do conteúdo imagético? Sugere ainda, um roteiro que auxilie a análise do campo iconográfico no qual questionamentos são feitos a partir dos elementos figurativos. A proposta favorece que os alunos descrevam, segundo suas percepções, as cenas e personagens marcantes. Ou seja, uma atividade que registra a percepção individual de cada discente para, posteriormente, ser compartilhada e submetida a um processo aprendizagem coletiva. Os diferentes olhares lançados sobre a imagem, que neste exemplo representa uma situação de violência, culminarão em uma síntese elaborada pelos próprios integrantes da atividade pedagógica. 
A contribuição de Santaella (2012, p. 64) sobre as formas de como ensinar através das imagens serviu para a criação de roteiros e da divisão da turma de alunos em pequenos grupos, o que facilitou o desenvolvimento das atividades propostas.

A leitura de imagens, neste caso, nada mais foi que uma profícua tentativa da prática de intersecção de saberes na produção de um outro conhecimento: respeitar o entendimento do outro, acatar opiniões diferentes, reverenciar a alteridade.

Nesta perspectiva, a atividade pedagógica para a leitura de imagens tornou-se um o exercício de transformação da sala de aula em um espaço para a afloração de percepções plurais e de prática do respeito ao outro. No desenvolver das atividades propostas, foi necessário extrair dos alunos o que só eles apreenderam acerca de uma imagem. Para tanto, o exercício da criticidade deve ser motivado como Alvarenga e Araújo (2006, p. 140) sublinham:

Nunca é demais enfatizar que a reflexão, como forma de pensar criticamente a realidade, de olhá-la com clareza, abrangência e profundidade, é de absoluta importância para o desenvolvimento do aluno. Por isso é importante que se encoraje e se melhore essa habilidade. Sendo os portfólios arquivos do aprendizado que têm como foco o trabalho dos alunos e sua reflexão sobre os mesmos, parece pertinente afirmar que essa ferramenta pode desenvolver o pensamento crítico e as habilidades que são a base dos processos de tomada de decisão em nossas vidas.

Para um processo reflexivo e que exercitou a crítica dos conteúdos visuais, vários itens que contemplam as imagens foram observados: planos, angulações, cores, traços e composições das figuras.

Vejamos, pois, os resultados da atividade aplicada em uma turma de História do Ensino Médio, a partir da leitura de La Paraguaya. 


\section{La Paraguaya que se deixa revelar e que também revela um pouco dos alunos}

Com o intuito de apresentar dados de uma atividade pedagógica sobre a leitura de imagem de cunho violento, fomos à prática, no início de dezembro de 2019. Aplicamos a atividade pedagógica para a leitura de imagens em uma turma de $2^{\circ}$ ano do Ensino Médio, de uma escola pública da rede estadual, na cidade de Mossoró (RN), composta por trinta e cinco alunos com idades entre 16 e 19 anos. O critério de escolha da unidade de ensino se deu porque a escola se situa em um bairro periférico em que os índices de violência são altos. De pronto, se intencionou observar as reações dos alunos que experenciam a violência quase que no dia a dia, quando se deparam com imagens de cunho violento.

Foi disponibilizada para a atividade a reprodução de La Paraguaya em papel A4, colorido, no modo resolução alta para que não houvesse comprometimento dos elementos da imagem; acompanhado, um questionário com seis perguntas. De forma sucinta, a professora titular da turma explicou o motivo da visita e solicitou cooperação dos trinta e cinco alunos presentes.

De posse da palavra, explicamos a atividade. Enquanto ocorria a explanação, observamos o ambiente da sala: as carteiras estavam todas enfileiradas, com pouco espaço para locomoção, claridade a desejar e pouca ventilação. Ao receberem o papel contendo La Paraguaya, os alunos foram orientados a somente observar a imagem por um minuto, para em seguida, responder as questões apresentadas.

A segunda parte da atividade consistia em responder individualmente às duas primeiras questões: a) você conhe a imagem? b) você já tinha ouvido falar do artista Juan Manuel Blanes?

O gráfico a seguir demonstra o resultado dessas duas questões 
Gráfico 01: Sobre a imagem e o artista.

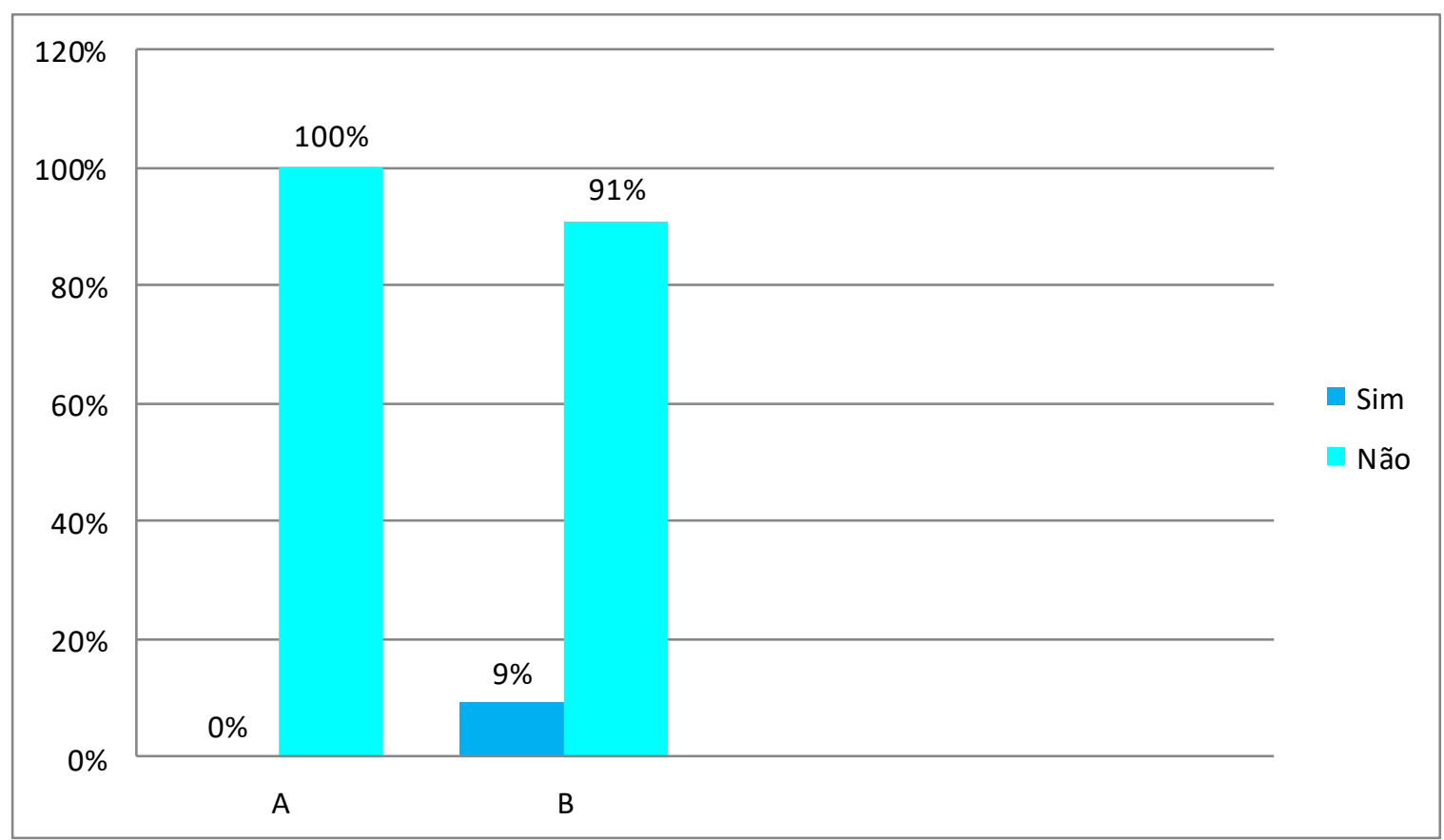

Fonte: Os autores

O gráfico 01 mostra que 100\% da turma não conhecia a imagem e que 91\% não tinha sequer ouvido falar, nem tão pouco lido algo sobre o artista. Somente 9\% disse que teve conhecimento sobre Juan Manuel Blanes por meio de documentários televisivos.

Bittencourt (2009, p. 330) ressalta que no momento da escolha de documentos para serem usados como fonte de ensino, o professor deve levar em consideração o ineditismo porque desperta mais interesse e curiosidade. Sendo assim, o fato de muitos alunos não conhecerem Blanes, foi interpretado como positivo, já que a inicial curiosidade abria portas para outras descobertas.

$\mathrm{Na}$ sequência da atividade, destacamos a forma como os alunos olharam fixamente a imagem. Constatamos que La Paraguaya prendeu-lhes a atenção de tal modo que o silêncio se fez presente sem que nenhum deles se dispersasse com conversas paralelas com algum colega; parecia existir somente uma comunhão, um diálogo entre o aluno e a imagem. Parecia haver uma identificação, como lembra Bittencourt (2009, p. 357) ao discorrer sobre atitudes dos alunos de 
História frente às fontes que lhes são próximas: “[...] por intermédio da observação ocorre a identificação e a descrição do objeto".

As duas questões seguintes se pautaram em questionar: c) qual o principal destaque da imagem? d) na imagem há algum elemento que você julgua violento e qual seria esse?

Vejamos os resultados apresentados pelo seguinte gráfico:

Gráfico 02: Principal destaque da imagem e elemento considerado violento.

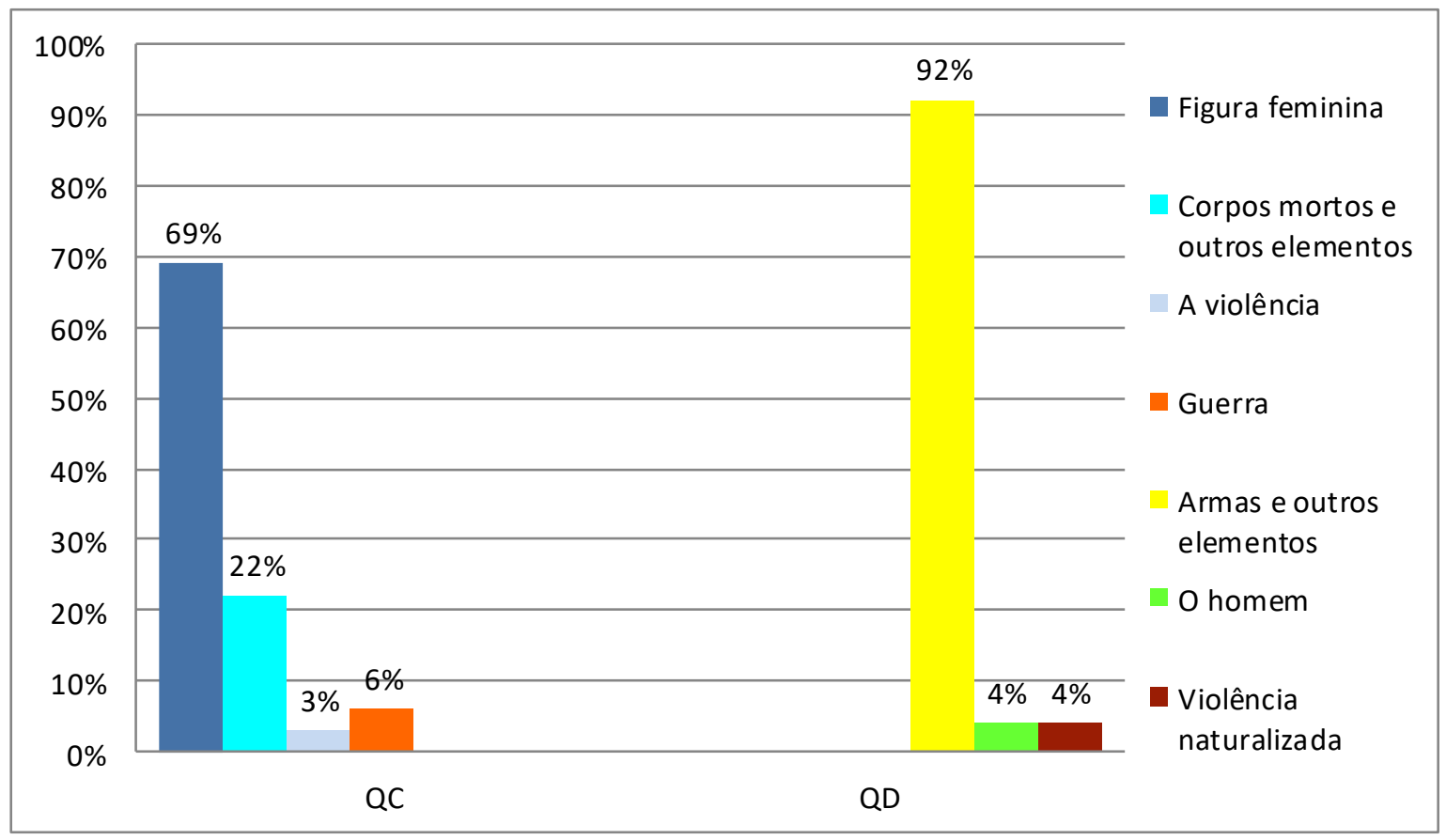

Fonte: Os autortes

Como resultado da questão "C", 69\% dos alunos apontaram a figura feminina como sendo o elemento de destaque de toda a cena iconografada. Em suas justificativas, os alunos destacaram a tristeza no semblante que certamente estaria ligada à situação trágica da guerra; outros destacaram o posicionamento centralizado da mulher no todo da imagem; além de perceberem que ela era a única sobrevivente do conflito.

Outros $22 \%$ do alunado informou que os corpos inertes caídos no chão tinham mais destaques; os $9 \%$ restantes apresentaram outros 
enquadramentos como figuras de destaque: a bandeira no chão, as aves de rapina, o lugar como cenário do conflito.

De acordo com Santaella (2012, p. 19), as várias apreensões mostram as múltiplas finalidades do olhar: "elas podem desde aguçar ou ampliar a capacidade perceptiva, a confirmar certa sensibilidade para se reproduzir o imaginário”.

Ao serem questionados se na imagem existia algum elemento da qual julgassem ser violento, 92\% dos alunos responderam que as armas eram artefatos de violência evidentes; $4 \%$ julgaram ser o elemento humano o mais violento por ser o causador de confrontos e guerras. E na última coluna, 4\% dos alunos disseram que na obra La Paraguaya não existia elementos de natureza violenta. De toda forma, sejam quais forem as perguntas, as respostas evidenciaram modos de entendimento sobre a violência antagônicos: desde a reprovação à apatia.

Segundo Bittencourt (2009, p. 190):

Nunca é demais enfatizar que a reflexão, como forma de pensar criticamente a realidade, de olhá-la com clareza, abrangência e profundidade, é de absoluta importância para o desenvolvimento do aluno.

Nesse sentido, caberia ao professor contextualizar não somente a imagem, mas também o que dela os alunos perceberam e o que a partir dela foi apreendido. A imagem portanto, não apenas ofereceu signos de representação, como também extraiu do aluno seus entendimentos, suas percepções de mundo, seus sentidos de existência. Uma via de mão dupla em que o conteúdo iconográfico protagonizou descobertas, porque perscrutou seus espectadores que se deixaram revelar por ele.

Vejamos então, os resultados das duas últimas questões "E" e "F" que trataram das sensações dos alunos frente à visualização da imagem de cunho violento. Atentemos para o gráfico abaixo. 
Gráfico 03: Sensações sentidas e a influência da imagem para práticas violentas

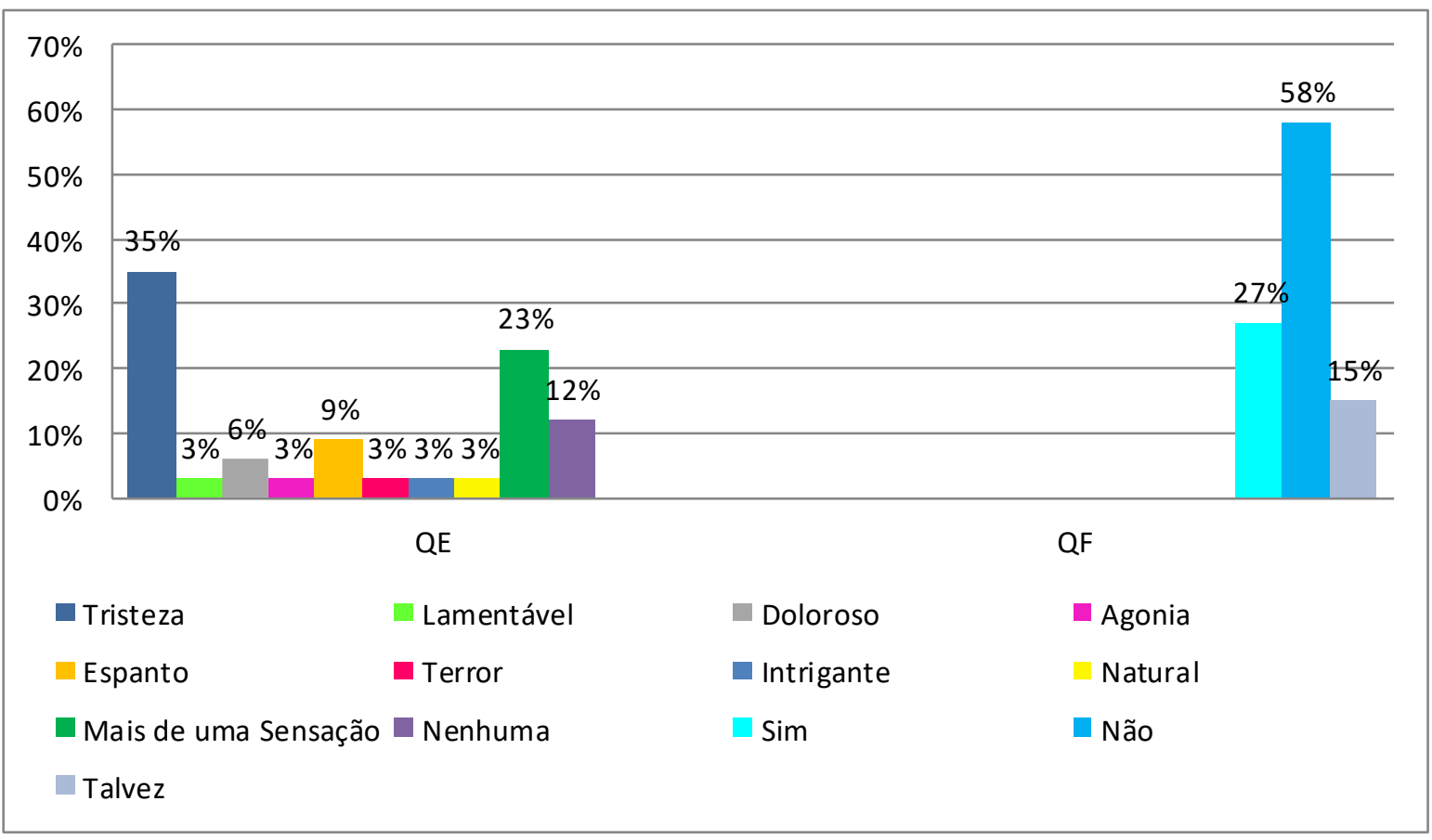

Fonte: Os autores

O propósito era mensurar, para além do impacto, o quanto a imagem despertava sensações ou impressões nos alunos que já viviam em um bairro violento. O cenário de tristeza da mulher figurada na cena de La Paraguaya facilmente foi reconhecido por 35\% do alunado; $3 \%$ informou que ambientes de conflitos são lamentáveis; 6\% disse que a cena provoca-lhe dor/piedade, pois durante o conflito provavelmente poderiam existir pessoas inocentes que foram mortas. Outros 3\% confirmou terem sentido agonia; 9\% sentiu espanto, devido à quantidade de corpos inertes e somente uma figura feminina como única sobrevivente. A sensação de terror somou 3\%. Nos casos em que a imagem despertou curiosidade, a sensação intrigante se encontra representado por $3 \%$.

A prática violenta vista como algo natural em 3\% foi justificada pelo fato de o cotidiano deles ser mais violento do que retratava a obra de Blanes. Os que informaram terem sentido mais de uma sensação corresponde a $23 \%$, enquanto $12 \%$ informaram não terem sentido nenhuma sensação. 
Dando sequência à atividade, a pergunta seguinte abordava não a imagem em si, mas o seu impacto. Quando os alunos foram questionados se a mostração de La Paraguaya incentivaria, de algum modo, práticas de violência, $27 \%$ disseram que SIM, uma vez que violência sempre origina mais violência. Contrários a essa ideia, 58\% disseram que NÃO, porque a imagem em si não poderia gerar violência, por se tratar apenas de um papel. E 15\% disseram TALVEZ, porque atos de violências são reflexos do estado de espírito do indivíduo e que, ao visualizar imagens de cunho violento, poderia aguçar práticas violentas. Embora reconheçamos que as perguntas feitas para medir o impacto de La Paraguaya nos alunos sejam demasiadamente simples, pretendíamos observar apenas o impacto do componente iconográfico e a respectiva influência em suas compreensões de mundo, suas percepções frente às realidades que enfrentavam.

Isto posto, foi possível observar a competência da imagem enquanto ferramenta pedagógica. Cada parte do componente imagético, quando submetida ao crivo do olhar, aguçou curiosidades, reflexões, ponderações e comparações. Logo, foi um experimento que motivou os alunos a opinar, a se deixar conhecer, a revelar um pouco de seus ambientes familiares e de relações cotidianas.

Mal sabiam eles que ao inquirirem sobre La Paraguaya acontecia, em contrapartida, um momento de desvelo de suas próprias percepções e entendimentos de mundo, uma redescoberta de si e sobre si mesmos.

\section{Considerações finais}

Reposicionar a visualidade no centro das discussões das práticas pedagógicas mais atuais é refletir sobre a atividade docente que se mostra dinâmica, aberta às capacitações e propensa aos melhoramentos.

Para Santaella (2012, p. 80), o ato de ler uma imagem deve ser entendido como uma decifração da linguagem visual. Portanto, La Paraguaya contribuiu para que os alunos sentissem e conhecessem o quanto estão habilitados ou não para a hermenêutica dos artefatos iconográficos. 
Para além de artefatos, as imagens se instituem fontes para 0 construto da História. Bittencourt (2009, p. 333) esclarece que o uso de imagens como fontes de ensino nas aulas de História auxilia o pensar histórico e dinamiza nos alunos uma consciência de pertença aos fatos e ao tempo. Em consequência disso, os alunos de História, presentes na atividade pedagógica, tornaram-se partícipes de um processo hermenêutico e perceptivo do próprio presente.

Nesse sentido, a observação silenciosa da imagem por um determinado tempo e a posterior equação do questionário, exercitaram os discentes em uma das práticas de ensino e de pesquisa mais fundamentais: a observação.

Logo, a sala de aula tornou-se um campo da prática de leitura de imagens que facilitou o Ensino. As experiências que envolveram o exercício de leitura e de interpretação de La Paraguaya objetivaram acostar os alunos às problemáticas da violência que têm se disseminadas no mundo de forma avassaladora, inclusive nos bairros em que habitam. A atividade pedagógica demonstrou que a sala de aula pode ser também um ambiente de mensuração das realidades experimentadas pelo corpo discente e docente, preparando alunos e professores para dar respostas às situações inesperadas, quando deles foram exigidas.

Portanto, discutir sobre as inúmeras possibilidades de uso das imagens no Ensino de História é contribuir para o entendimento do homem no mundo, tecido por relações e pela argúcia de se postar frente aos desafios. Porque as representações de realidades conflitantes fazem parte dos capítulos que compõem os livros didáticos, cabe também ao professor saber reaproveitar os conteúdos imagéticos, ainda que de cunho violento, para contemporaneizar temáticas, trazer para o presente as inquietações, escutar as possíveis soluções trazidas pelas falas de seus alunos.

A interdisciplinaridade que presentifica e caracteriza o ensino mais promissor favorece uma pluralidade de práticas pedagógicas e a participação mais efetiva dos discentes. A experiência de tornar a sala de aula em um espaço do exercício para a leitura de imagem favoreceu 
uma recriação do ambiente escolar capaz de produzir conhecimentos a partir dos contextos de vivência. As vozes dos alunos, suas impressões e ponderações foram levadas em conta.

Ao se utilizar imagens como fonte histórica e de ensino, na prática escolar, o professor de História licencia seus alunos a refletir sobre as intenções, as mensagens veladas, o instituído, o já dado. Portanto, saber ler uma imagem, uma figura, um ícone é letrar-se também naquilo que vai além de frases, períodos longos e complexos. É contemplar a figura e extrair dela justamente o que as frases e as sentenças silenciam.

Ao refletir sobre a imagem de La Paraguaya, tentou-se dar visibilidade àquilo que os alunos perceberam sobre possíveis atos violentos que a imagem expunha e como se posicionavam frente à manifestação da violência. Desde a taxativa reprovação à indiferenaça, os alunos deixaram suas impressões como espelho de suas vivências. Desta maneira, a atividade pedagógica tentou trazer para o ambiente da sala de aula a vida de seus alunos, suas impressões, modos e percepções daquilo que os cercam. Novamente a permuta e a troca de experiências do presente se fizeram conteúdos de discussões para aulas de História, que em uma compreensão rasa da disciplina, só falaria das coisas do passado. Os marcos cronológicos nesta acepção, diluem-se para deixar que as temáticas mais relevantes se acresçam ao planejamento de uma aula que leva em consideração os temas atuais.

A atividade didática mostrou também que as imagens prendem a atenção do alunado para o fato de a violência existir e estar presente, por vezes, de modo, subliminar, inclusive nos livros didáticos.

Se a imagem tem a capacidade de revelar o não dito, o não dizível a La Paraguaya não se fez de rogada. A mostração de uma mulher entristecida ocupando o centro da tela, veicula as consequências dos conflitos. Isto foi o que, a princípio, alguns alunos olharam, perceberam, notaram. Contudo, a figura de La Paraguaya também olhará o aluno, também espiará suas reações, escanceará suas concepções de mundo e 
como lidam com as diferenças. A ilustração deixará de ser uma figura comum e se postará como protótipo de um recomeço para reflexões mais adensadas sobre a presença de imagens nos livros didáticos. Deixará de ser apenas um desenho para se revelar como um fenômeno visual capaz de sacudir as certezas de que só os livros ensinam. O que era a princípio, um rastro, um modo de narrar o passado sobre as cruezas da vida, pode representar, em sala de aula, no presente, um modo novo de deixar-se enxergar pelas imagens.

\section{Referências}

ALVARENGA, Georfravia Montoza; ARAÚJO, Zilda Rossi. Portfólio: conceitos básicos e indicações para utilização. Estudos em avaliação educacional. v. $17, \mathrm{n}^{\mathrm{o}}$. 33, jan./abr., 2006. DOI:

https://doi.org/10.18222/eae173320062131.

BITTENCOURT, Circe Maria Fernandes. Ensino de história: fundamentos e métodos. $3^{\text {a }}$. ed. São Paulo: Cortez, 2009.

BOULOS JÚNIOR, Alfredo. História sociedade \& cidadania: $2^{\mathrm{a}}$ ano - Ensino Médio. 1ed. São Paulo: FTD, 2013.

BURKE, Peter. Testemunha ocular: história e imagem. Tradução Vera Maria Xavier dos Santos; revisão técnica Daniel Aarão Reis Filho. Bauru, SP: EDUSC, 2004.

ELLOA, Emmanuel. Entre a transparência e a opacidade - o que a imagem dá a pensar. In: Pensar a imagem/ Emmanuel Alloa (Org). $1^{\mathrm{a}}$. ed.; $2^{\mathrm{a}}$. reimp. Belo Horizonte: Autêntica Editora, 2017.

BOEHM, Gottfried. Aquilo que se mostra. Sobre a diferença icônica. In: Pensar a imagem/ Emmanuel Alloa (Org). $1^{\mathrm{a}}$. ed.; $2^{\mathrm{a}}$. reimp. Belo Horizonte: Autêntica Editora, 2017.

FONSECA, Selva Guimarães. Didática e prática de ensino de história: experiências, reflexões e aprendizados. Campinas, SP: Papirus, 2003. Coleção Magistério: Formação e Trabalho Pedagógico. 
MONTEIRO, Ana Maria Ferreira da Costa; PENNA, Fernando de Araújo. Ensino de História: saberes em lugar de fronteira. In:

Realidade. Porto Alegre, v.36, nº. 1, p.191-211, jan./abr., 2011. Educação e

SANTAELLA, Lucia. Leitura de imagens. São Paulo: Editora Melhoramentos, 2012.

SANTAELLA, Lucia \& NÖTH, Winfried. Imagem, cognição, semiótica, mídia. São Paulo: Iluminuras, 1998.

TAMANINI, Paulo Augusto. O Holodomor e a memória da fome dos ucranianos (1931-1933): o ressentimento na História. Projeto História: Revista do Programa de Estudos Pós-Graduação de História, v. 64, 2019. DOI: https://doi.org/10.23925/2176-2767.2019v64p154-184.

TAMANINI, Paulo Augusto; MORAIS, Ana Meyre de. O ensino de História e as imagens postas: a redenção de Caim como fonte de (des) informação sobre a escravidão no Brasil. In: Proposituras: ensino e saberes sob um enfoque interdisciplinar. Paulo Augusto Tamanini. (Org.). São Carlos: Pedro \& João Editores, 2018. 